\title{
'Sou quem sou, e não sou nada, sou uma história já contada': Sujeitos cênicos - expressão erótica na obra audiovisual de Ney Matogrosso no contexto de autoritarismo (1975-1982)
}

\author{
"I am, I am nothing, I am a story ever told": Performing personas - \\ erotic expression in audiovisual performances Ney Matogrosso the \\ authorization context of a dictatorship
}

Robson Pereira da Silva*

RESUMO

Verifica-se no presente artigo as investigações acerca das transgressões performáticas de Ney Matogrosso, no contexto da ditadura civil militar brasileira. Desta feita, percebe-se a exibição de sujeitos (tipos/arquétipos) marginais, nos procedimentos performáticos (fonograma, capa, encarte, espetáculo) que configuraram o sentido das obras do artista, durante as décadas 1970 e 1980. Em suas obras, Ney Matogrosso, inverteu a ideia regida pela cultura afluente, em procedimentos compostos por materiais audiovisuais dispostos e difundidos em uma indústria cultural, o que garantiu historicamente a materialidade da produção do intérprete na Música Popular Brasileira. Em consequência disso, temos o acesso ao registro da performance. Neste estudo, preconiza-se a historicidade da estética da subversão posta nas obras de Ney Matogrosso, como uma atitude política frente ao regime de autoritarismo produtor de interdições do potencial erótico.

Palavras-chave: Performance. Ney Matogrosso. Autoritarismo. MPB. Ditadura. Três. Palavras. Chave.

* - Mestrando do PPGHIS/UFG, membro do grupo de pesquisa Arte.com. Pesquisa fomentada pela Coordenação de Aperfeiçoamento de Pessoal de Nível Superior (Capes). 


\section{ABSTRACT}

There is, in this article, the research into the performing transgressions of Ney Matogrosso in the context of the Brazilian dictatorship civil military. Thus, we understand the marginal personas (types / archetypes) displayed procedurally in performative procedures artist Ney Matogrosso (phonogram, cover, brochure, spectacles), meaning his work over the years 1970 and 1980. The artist, in his works, reverses the concepts governed by affluent culture, this practice, consisting of audiovisual materials, widespread in the cultural industry, which ensures historically the performer of the production of the materiality of Music Popular Brazilian (MPB) - recording performance. This study highlights the historicity of aesthetic subversion in Ney Matogrosso, as a front political attitude to the producer authoritarian regime prohibitions the erotic potential.

\section{Canções, momentos, imagens... construção performática}

Investigar as obras musicais, mais precisamente as dimensões audiovisuais de Ney Matogrosso, não se faz significativo somente por se tratar de um dos maiores performers da música popular brasileira, mas trata-se de observar a sua produção musical como combinações cênicas e imagéticas, que emanaram formas de representar sujeitos liminares/marginais ${ }^{1}$ diante da realidade política de autoritarismo.

No momento em que Ney Matogrosso iniciou sua carreira solo, o país já encontrava propenso à abertura política - "lenta, gradual e segura". As produções do artista, entre os anos de 1975-1982, são as que nos interessa na presente pesquisa. De tal modo, considera-se aqui, a capacidade artística de Ney Matogrosso em processar e projetar experiências humanas e históricas, e até mesmo transcender, no sentido de projetar no campo da construção simbólica horizontes de expectativas, como "índice de apresentação" (NORONHA, 2005, p.26).

Por esse viés, Ney Matogrosso, é visto como propulsor de interpretações singulares de canções de compositores (já consagrados) da Musica Popular Brasileira (Mpb), como Chico Buarque, João Bosco, Rosinha de Valença, Sueli Costa, entre outros. Ao interpretar essas canções, por vezes já gravadas, nos instiga a pensar qual a dimensão de um interprete no período da ditadura militar. Ainda, mais especificamente, o que o difere do cantor/compositor.

\footnotetext{
1 Consideramos liminaridade, mas, próximo da concepção liminóide que se aplica a sociedades pós-industriais, na perspectiva de Victor Turner, que consiste em emanar a condição de ambiguidade e paradoxo que a cultura, sobretudo pelos dramas sociais, ou mais especificamente na esfera ritual, ou seja, a cultura se mostra em sua face dialética, pois é no contraditório que se faz a experiência simbólica. Tal perspectiva é demandada da proximidade intencionada por Turner nas interfaces entre Teatro e Antropologia. (TURNER, 2008).
} 
Pensamos a atuação do interprete como ampliação do texto de tais compositores, sendo a composição a fonte primeira do processo de construção, escolhida como ponto inicial da produção performática. Ney Matogrosso tomou essa ampliação, a partir da captação construtiva do audiovisual, na interface som, cena e imagem, constituindo assim, a singularidade de sua maneira de produzir arte, uma capacidade autoral a fim de marcar a música popular como fenômeno cultural visualmente apresentável.

Ao escolher um repertório de composições musicais um artista como Ney Matogrosso, intelectualmente, mesmo que negue o rótulo de intelectual, visualiza nas canções a dimensão política e estética nelas imbricadas; assim, tende demarcar simbolicamente as expressões que confluam com a experiência que pretende exibir. Essa perspectiva é firmada pelos meios em que o artista formatou, de maneira peculiar, a expressão de universos simbólicos que atrelasse canção, imagem e cena, como experiência de subversão.

A escolhas de repertório estiveram ligadas a uma forma, ou ao processo de comprazer a irrupção de o sentido ritual, em que o artista comprometeu sua obra e, assim, ampliar a dos compositores. No caso aqui estudado, a exibição se desenvolve em todos os processos performativos da construção das obras (canção, disco e identidade visual, videoclipe, espetáculo); articula-se dessa maneira a estética da subversão.

A partir da observação pretendida neste trabalho, é possível perceber que Ney Matogrosso mesmo que oportunamente pelas condições materiais e históricas por ele conquistadas, nos embates do campo da música popular brasileira, constituiu a viabilidade da emergência de cenas/imagens/musicais - o audiovisual. Ademais, essas condições o permitiram significar as suas experiências em diálogo com as coletivas, a partir da inferência simbólica produzida pelo interprete naquele contexto.

Entendemos que se construiu ângulos de percepção, alternativas e expectativas sócio históricas no campo dialético da Mpb, na sobreposição de interesses sob a voz e a figura do artista Ney Matogrosso, de diretores de gravadoras ao público. Com isso, o artista não invalidou suas pretensões de ação estética, decidindo bifurcar o contexto para compor sua experiência como emissor de sensibilidades, toma a projeção como operação estética. ${ }^{2}$

A Imagem, nesse caso, comporta-se enquanto transformadora da condição da música, em consequência da alteração de formas de produzir sentido no ato de escuta aliado a visibilidade, na articulação de [áudio] visualidades produzidas com a finalidade de enunciar sujeitos cênicos, o que fez com eficácia a arte de Ney Matogrosso, portadora de intenções subversivas, mesmo

2 Segundo Marcio Pizarro Noronha (2005, p.23)., as projeções incidem em pensar o objeto artístico na medida em que coloca em execução as significações personificadas em sua materialidade - em pensar pelas sensações, como operação estética, capaz de projetar "o modo como certo fragmento de conteúdo retirado do mundo se presentifica visual e materialmente no seu entorno e se torna o leitmov (motivo) existencial." Sendo esse o oriente de formulações das ações do artista e de sua obra pelos perceptos [sic] e afetos. (NORONHA, 2004, p.23-27). 
considerando as condições com as quais o artista teve que negociar. É esse projeto artístico que consideramos um liminóide, no contexto de repressão da ditadura-civil militar no Brasil.

Ou seja, esse projeto por meio de um mecanismo de cultura, mesmo ligado a uma indústria cultural, tendeu a expressar/exibir tramas sociais, emanou opções de ultrapassagem da configuração social instaurada. Exibiu complexidades nas "tramas do cotidiano nos grandes cenários", uma consciência individual exerceu sua potencialidade simbólica, a fim de expor uma sociedade, ou, suas projeções experienciais sobre ela.

Portanto, quando Ney Matogrosso se apropria do "texto" de um compositor, implica sua experiência na construção simbólica pela voz e corporeidade sobre esse referido material. Desse modo, os processos de construção de uma performance artística podem pela oralidade/vocalização, ou melhor, pela corporeidade, emitir signos que vinculam ações; exibindo-as em seu caráter simbólico. Destarte, a obra de Ney Matogrosso a partir desses parâmetros, por meio de sua construção processual, enunciou sujeitos liminares que puderam oportunizar a experiência da subversão.

Em consequência disso, não devemos encarar a obra de um interprete de música popular como mero produto massivo, pois, a arte é emissora de insígnias do momento histórico em que se desenvolve. A arte obriga-nos a percebê-la em sua capacidade de aderência, recepção e produção de cultura. Desse modo, o know-how de Ney Matogrosso catalisa-se por meio de sua construção vocal e corpórea, na incidência evocativa da construção imagética e sonora de sujeitos liminares impressos na materialidade das obras. Deve-se, então, integralmente ser encarado como uma performance.

Paul Zumthor (2007, p.10) indica a voz como um fenômeno ativo da cultura, em suas palavras: "um fenômeno central" que oportuniza a capacidade dos indivíduos e sociedades de se representarem por uma corporeidade. Dessa maneira, corpo e voz funcionam como realizador da linguagem, porém, diferente de uma dada escritura:

Por sua vez, esses mesmos media diferem da escrita por um traço capital: o que eles transmitem é percebido pelo ouvido (e eventualmente pela vista), mas não pode ser lido propriamente, isto é, decifrado visualmente como um conjunto de signos codificados da linguagem. É então possível (e essa opinião é a mais comum) ver nos meios auditivos uma espécie de revanche, de retorno forçado da voz, e ainda mais do que a voz, porque com o filme ou tevê vê-se uma imagem fotográfica e, talvez, ainda em breve, tenha-se a percepção do volume. (ZUMTHOR, 2007, p.14-15) 
A partir dessa perspectiva, mas acreditando que o audiovisual comporta um conjunto de signos, acusamos que a obra de Ney Matogrosso durante os "anos de chumbo" lançou mão de imagens e sonoridades do texto de compositores. Assim, visibiliza-se a inclinação de um interprete em gerar vivacidade e intensidade simbólica, na ampliação de textos que, primeiramente, se apresentaram na transposição da oralidade para escrita, a qual o intérprete inverte a lógica.

Por essa capacidade de articulação de mídias, Ney Matogrosso procurou significar o mundo por meio da proposição da transgressão erótica, em meio ao contexto de fragmentação 3 proporcionada pelo arranjo social tecnocrata. Isso significa dizer: que transparece uma força criativa frente a "dificuldade de significar o mundo" (DAWSEY, 2007, p.571).

Os processos performativos que habilitam a performance de Ney Matogrosso, constituem-se em uma transação que a partir da enunciação ${ }^{4}$ destinou-se à liminaridade de apresentação (cênica, sonora, imagética) de sujeitos que, na ordem das estruturas sociais, se encontram em estado marginal, como a figura do índio, do bandido, ciganos, etc. Sujeitos que não faziam parte do projeto de sociedade imaginada pelo projeto político civil-militar.

Desse modo, o artista construiu um pensamento de subversão em todas as etapas que conferiram sentido sobre sua performance - fonograma, capa/encarte, videoclipe, espetáculo, firmase assim uma autobiografia de si, das experiências nas mídias. Ney Matogrosso construiu uma linguagem performativa da transgressão na Música Popular Brasileira (MPB), a performance que vincula discurso, como na literatura e suas formas:

O pensamento lógico, literal, tem uma forma característica, que é conhecida como "discursiva", por que é forma do discurso. A linguagem é o instrumento fundamental do pensamento, e o produto traz o selo do instrumento que o molda. (LANGER, 2011, p.314).

\footnotetext{
3 Forçada também pelas próprias condições da indústria fonográfica na construção da "imagem pública do artista" (entrevista, material de divulgação de discos, reportagens, etc.), a fim de comprometer os produtos finais ao seu destino preconizado, o consumo, pelas grandes companhias (gravadoras) responsáveis pela esfera de produção e comercialização de disco. Mas no caso de Ney Matogrosso há uma apropriação desse processo para emanar significantes audiovisuais do seu compromisso com uma estética da subversão, exemplo disso é a construção de videoclipes que reafirmaram o sujeito cênico enunciado primeiramente no disco (produto de consumo substanciado anteriormente por uma força de produção criativa), reafirmado nos espetáculos do artista. Configura-se, então, uma capacidade criativa performance enquadrada no processo estrutural que mantem e difunde as intenções artísticas. Isso, por exemplo, possibilitou a construção poética do documentário Olho Nu, por Joel Pizzini, sobre a carreira de Ney Matogrosso. Sobre aspectos de funcionamento da indústria fonográfica e o mercado brasileiro de discos e suas relações sócio antropológicas na década de 1970. (MORELLI, 2009).

4 Capacidade de interlocução entre discursos, uma "polifonia discursiva" em um enunciado, como firma Bakhtin e seus comentadores (BRAIT, 2013, p.62, 65). Dessa polifonia emanam as condições e interações que possibilitam a constituição do enunciado. Nesta pesquisa a enunciação consiste na composição de um texto que credencia outro, possibilitando o aprofundamento do significado "para além da identificação" (BRAIT, 2013, p.69). A enunciação explana os indicadores de interlocução e intersubjetividade que dispõe a circulação e articulação de discursos, confronta a construção sociocultural e histórica que a faz emergir. (BRAIT, 2013).
} 
Susane Langer afirma que a arte é a experiência que marca o homem, exibe as marcas e o desejo de um indivíduo, mas a fim de expressar-se, passa por conveniências que demarcam a atuação de latência na vitalidade humana:

A arte, como discurso, é em toda parte marca do homem. Tal como a linguagem, sempre que ocorre divide-se em palavras e adquire convenções para misturar os padrões dessas palavras semi-independentes, a fim de expressar proposições, do mesmo modo a gramatica da visão artística desenvolve formas plásticas para a expressão de ritmos vitais básicos. (LANGER, 2011, p.65).

Pela via estética calcada principalmente no erotismo que, segundo Severo Sardy (1979), formata-se como tendência que ultrapassa o pensamento. Então, por essa via, Ney Matogrosso introduziu nas obras o pensamento permeado pelo erotismo.

\section{Erotização dos textos ... "áudio/visão" da subversão}

Sob a égide dessas questões supracitadas, a obra de Ney Matogrosso é vista como um veículo de contestação que se ajusta como dispositivo de apresentação e de sublimação da realidade, porém, apreciando alternativas estéticas ao contexto de uma sociedade autoritária e controladora do Eros.

A sociedade reguladora buscou, historicamente, o congelamento da força criativa constitutiva do ser (erótica), ou seja, configura Eros interditado, como nos orienta Vilma Figueiredo (1992). Intensifica-se, nesses momentos de repressão, a empatia da capacidade da construção social pelo impulso, o agir do ser. Mas é própria de Eros a intenção e potencialidade de ação e resistência, "Eros resiste a todo exorcismo a que foi submetido e manifesta-se como pode, aguardando a moldura de tempos mais favoráveis a seu culto" (FIGUEIREDO, 1992, p. 85). Nessa perspectiva, encaramos a performance de Ney Matogrosso, como uma ode a libertação de Eros $^{5}$.

5 Como expressão política de luta pela vida diante da aparência de liberdade, ou mesmo, aparente liberdade sexual remetida a condições de repressão de um simulacro de liberdade prefigurada na liberdade econômica de uma produtividade agressiva sobre os indivíduos e suas subjetividades. (MARCUSE, 1975). 
Em 1975, Ney Matogrosso iniciou a carreira solo, após deixar o grupo musical Secos \& Molhados, seu caminho estético já se delineava no primeiro disco - Água do Céu Pássaro (1975) que não destoava da experiência artística adquirida no grupo supracitado. O itinerário estético de Ney Matogrosso enveredou por um projeto estético de libertação/subversão que, em um primeiro balanço da obra do artista, pode verificar-se por meio de três eixos temáticos de cunho sócio antropológico: agressividade, sexualidade, humor (deboche e irreverência).

A forma pela qual Ney Matogrosso conseguiu exprimir suas propostas estéticas naquele contexto, foi a sobrevalorização a ação do corpo. Esse percurso vinculado com os processos da construção da obra - a performance, se tornou complexo, pois o mecanismo de difusão das propostas artísticas do cantor se iniciara com o apoio da indústria fonográfica ligada a formatação da Indústria Cultural já afirmada no Brasil; afinal, o disco é o primeiro produto a vincular o enunciado em que o artista emana suas intenções performáticas, pelas músicas escolhidas e arte gráfica do álbum.

Destarte, a Indústria Cultural no que tange a obra de Ney Matogrosso, não se compreende como um mecanismo determinante, mas como um "limitador e executor de pressões; parte das tensões do artista", como aponta Raymond Williams (2005). Neste caso, a Indústria Cultural é vista como mediadora, uma estratégia de autonomia e transgressão de Ney Matogrosso, como afirmou o sociólogo Flávio de Araújo Queiroz, é como "sentimento contramão [...] dá-se a partir de então, a condição de liminaridade do cantor frente ao regime militar, a indústria fonográfica e à mídia dentro do percurso de sua carreira solo, onde estabeleceu a construção do corpo transgressor do artista na busca de sua autonomia artística" (QUEIROZ, 2009, p.257).

Então o elo entre a obra do artista e os vínculos com os quais ela teve que se relacionar, não de maneira harmônica, tencionou, limitou, mas não necessariamente anulou os impulsos libidinosos que a mesma buscou difundir.

Apesar das ressalvas sobre a indústria cultural, nos dedicamos nesta pesquisa, à forma pela qual o artista compôs a sua estética da subversão performaticamente, contra ao estado de exceção que congelou as sensibilidades artísticas brasileiras. Compreendemos a estética da libertação, a partir das orientações de Hebert Marcuse (1981) que, teoricamente, sugere uma força política da forma estética na configuração do conteúdo, na significação e sugestão de uma alternativa à sociedade estabelecida que, por sua vez, reprime as potencialidades de vontade criativa do homem.

Essa "dimensão estética" indica a concepção que acusa a realidade, mas concomitantemente denota as possibilidades de liberdade frente as configurações repressivas engendradas historicamente no campo social. Desse modo, a arte aponta para a realidade - parte dela, mas figura uma contestação num formato que a supera, a transcende, como o autor explica: 
As qualidades radicais da arte, ou seja, sua acusação da realidade estabelecida e sua invocação da bela imagem (Schoner, Schein) da libertação baseiam-se precisamente nas dimensões em que a arte transcende a sua determinação social e se emancipa a partir do universo real do discurso e do comportamento, preservando, no entanto, a sua presença esmagadora. Assim, a arte cria o mundo em que a subversão da experiência própria da arte se torna possível; o mundo formado pela arte é reconhecido como uma realidade suprimida e distorcida da realidade existente. Esta experiência culmina em situações extremas (do amor, da morte, da culpa e do fracasso, mas também da alegria da felicidade e da realização) que explodem na realidade existente em nome de uma verdade normalmente negada, ou mesmo ignorada. A lógica interna da obra de arte termina na emergência de outra razão, outra sensibilidade, que desafiam a racionalidade e a sensibilidade incorporadas nas instituições sociais dominantes. (MARCUSE, 1981, p. 19-20).

A potencialidade criativa imbricada na proposta de performance de Ney Matogrosso, consiste essencialmente no trajeto explícito na continência interartística/intermidiática ${ }^{6}$ de suas obras.

\section{Processos nas intermídias}

Se não bastasse o fonograma que é a primeira produção que o cantor realiza (escolha de canção/texto/poesia/arranjo - vocalização) com o auxílio de músicos, produtor; por conseguinte, se constrói junto ao diretor gráfico e fotógrafo o projeto gráfico para comportar o fonograma (capa/embalagem/encarte - imagem), apresenta-se como um "paratexto", enunciado primeiro na tendência intermidiática. (CLUVER, 2007, p.11).

Logo após essa etapa, se constroem-se ações televisivas, como videoclipes (imagem/vídeo/música). Por fim, o espetáculo, onde a obra se corporifica performaticamente em sua plenitude, reimprimindo todas as fases anteriores da construção da obra no corpo do artista em diálogo com o público. Nota-se, então, o trajeto assegurado pela enunciação.

6 Entendemos como a capacidade do artista em combinar mídias, na construção de uma linha performática em que as articula. É essa a garantia processual que define a eficácia simbólica dos signos enunciados por Ney Matogrosso. (CLUVER, 2007, p.15-16). 
A linha performática expressa no processo de enunciação, não precisa necessariamente ocorrer nessa sequência de atividades artísticas que envolvem a significação mediada das obras. Trata-se de componentes oportunizados no campo da Mpb, como condições para as produções artísticas, porém, como uma força produtiva que, em todos esses níveis, passa pelo corpo do artista que com elas negocia.

Sob essa óptica, o trabalho do cantor expandido na condição de performer atrela-se a "multimídialidade"7, precisando a intenção performática na construção de sentido que emana a simbolização da subversão, firmando-se em sistemas de signos diferentes que, autonomamente, não exprimiriam de forma autossuficiente uma significação do projeto performático do artista ${ }^{8}$.

Essa possibilidade intermidiática, em sua materialidade, se fez a partir do momento em que alterou-se a recepção da mídia musical, trilhando a passagem de configuração da música ao vivo ao registro de gravação, sobretudo, de forma mais intensa, no pós-guerras mundiais, valorizada pela intensificação da Indústria Cultual. Desse modo, ampliou-se a percepção da própria concepção do que se conferia por música:

Até a invenção das técnicas de gravação, a música era recebida ao vivo (ou por escrito, na leitura da partitura) — na igreja, nos salões de concerto, no ambiente de trabalho ou no lar (muitas vezes com o receptor participando da performance). Performance, local, ocasião, função - tudo isso condicionou (e continua a condicionar) a recepção, o que inclui também sensações visuais e espaciais. A gravação e os mecanismos de distribuir, reproduzir e ouvir gravações, até os meios modernos de regravar gravações recebidas pela internet, mudou e qualificou profundamente a recepção. Além dos meios tecnológicos de transmissão, capazes de modificar o próprio som, são os meios de distribuição, inclusive os "paratextos" da embalagem e do design da capa, que influem em nossa recepção de um texto musical (os últimos sendo aspectos intermidiáticos). Outros fatores importantes no consumo de produtos musicais são a publicidade e as reportagens e críticas nas mídias públicas. E desde o mundo antigo os próprios artistas, não só como intérpretes, mas também como ídolos de elites ou de massas, têm tido um papel importante na recepção e também na produção de música. (CLÜVER, 2007, p. 11)

7(Texto, imagem, som, cena, vocalização, todos esses elementos constituem e se materializam no corpo/performance). Inter-relação de mídias em uma composição textual única. (CLUVER, 2007, p.15).

8 Consiste em uma combinação de signos e mídias. (CLUVER, 2007, p. 15). 
Isso nos alerta que o corpo como expoente de força da ação, incumbido por Eros, produz imagens, ou melhor, visualidades e sonoridades em prol da libertação, materializada na interrelação de produtos culturais. Esse corpo na captado em áudio e vídeo sugere a ambiência de libertação subversiva, se presentifica nas [inter]passagens, nos processos midiáticos e sua recepção.

No que se refere a atuação artística de Ney Matogrosso, em uma "partilha do sensível" (RANCIERE, 2009) da subversão, observamos que a ação interartística o conduziu à combinação de mídias que, a princípio, poderia se apresentar em desconexas mídias em um produto meramente musical, que apelasse somente em exprimir o canto no ato de gravar um disco, ou seja, delimitar a atividade do cantor em cantar, ou somente interpretar, porém, Ney Matogrosso, fixou-se na MPB justamente na ultrapassagem disso.

Não obstante, o artista com tal perspectiva de execução de sua obra, no sentido em que a escolha e o gesto não se apresentam arbitrários, destina-se pelo viés intermidiático cumprir uma narrativa sensível que, oportunamente, Ihe permita colocar em cena sujeitos do cotidiano, e até mesmo arquétipos que corrompam a manutenção de um status quo à moda brasileira. Esses sujeitos se tornaram performaticamente a figuração do discurso da subversão do artista, contra a repressão e opressão de um contexto autoritário.

Tais figurações incorporadas por Ney Matogrosso, se apresentaram pelo homem primitivo - a construção do Homem de Neandertal, em Água do Céu Pássaro (1975); o bandido alegórico, em Bandido (1976); o índio, vocalizador de demandas sinalizadas pela inversão, no contexto da reabertura política, em Mato Grosso (1982).

Não haveria escolha mais propícia do que esses sujeitos não apreciados, por vezes banidos, de um projeto moderno regulado pela vigência de uma ditadura militar, que não os enxergava como participantes da conduta sociopolítica, em que se visou uma perspectiva hegemônica de "minorias" sobre eles, ou seja, são sujeitos marginais e liminares.

Portanto, esses personagens corporificados em Ney Matogrosso vocalizaram subversões aos que os oprimem, sobretudo, exprimem a sexualidade e o desejo como arma a favor da sua própria condição de liminaridade, como alternativa ao autoritarismo e a submissão. Mesmo que isso seja um projeto individual do artista posto em cena pública, mas se estendeu à medida em que invadiu a experiência coletiva no ato de escuta e exibição pública. Sumariamente, confirma-se uma partilha do sensível que revela a transgressão, de modo que esse projeto estético proceda como uma prática social e política.

No documentário Olho $\mathrm{Nu}$ (2012), Ney Matogrosso emerge no emaranhado de materiais que compuseram sua obra, como se apresentasse uma etnografia de si, entre imagens, sons, entrevistas, em uma análise cênica que a dinâmica do próprio documentário permite. Exprime-se nesse objeto de arte avaliações do projeto estético do artista, do começo ao fim. No decorrer do 
filme, Ney Matogrosso expressa o impacto de sua proposta de performance, onde comenta: " $E u$ adoro ser subversivo, em todos os governos que passarem, eu serei subversivo, eu só sei ser subversivo" (PIZZINI, 2012) [grifo meu].

Com esta afirmação, somada as imagens do homem primitivo do espetáculo Homem de Neanderthal (1975), o documentário que figura a construção da memória artística de Ney Matogrosso, também pontua a construção artística visada no processo intermidiático, na evidenciação da estética da subversão que o artista construiu ao longo de quatro décadas de carreira, reafirmada mais uma vez na construção cinematográfica.

\section{O Homem primitivo e o despertar da América do Sul}

O primeiro sujeito liminar que Ney Matogrosso dimensionou em cena, foi o homem fundido com o animal, no intento de construir sua representação do homem primitivo, em Água do Céu - Pássaro e seu respectivo show, imagem audiovisual reiterada no seu primeiro videoclipe - América do Sul (1975).

Nessa linhagem performática que articula canção, imagem e encenação, o artista construiu por meio da corporificação desses personagens, simbolizadores, em caráter ritualístico, dos ideais de liberdade, comportados pela sobrecarga libertária da sexualidade. No caso do homem primitivo, que enfatizava uma perspectiva ecológica do artista, reafirmava-se a ligação sexual entre homem e natureza, insinuando uma composição liminar entre o estado humano e o animal, como uma dimensão de ambivalência e ambiguidade, o sentido liminar dessa relação.

O sentido liminar, exposto em Victor Turner (2005, p. 143), é a atuação aquém do processo estrutural que engrena a sociedade, como as distinções sexuais que "são componentes importantes da posição estrutural, num reino sem estruturas, não vigoram"

Como um processo de renúncia e denúncia da realidade, Ney Matogrosso, definido pela libido do personagem, nega a condição estrutural usando-se da sexualidade e da natureza, como afirmou em 1977 no documentário Metamorfose: "o animal tem uma coisa, nasce livre, o destino dele é viver livre".

Nesse sentido, em Água do Céu Pássaro, Ney Matogrosso reimprimiu o corpo na difusão de visualidades sonoras, em que ritualisticamente investiu no processo de liminaridade que comporta 0 paradoxo na identidade do ser. Assim, na equiparação entre o humano e a natureza num caráter de interstício, convoca-se a quebra com a postura hierárquica provocada pelo regime autoritário, afinal 


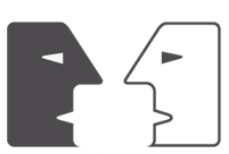

ANTÍTESES

a ação simbólica reduz a distância que o conjunto social impõe a Eros. Há na fusão do homem com o animal um apagamento do "status e a distância social dos homens" (TURNER, 2005, p.156).

Figura 1 - O personagem liminar é enunciado primeiramente pela via imagética, atrela-se como um pretexto das intenções do fonograma

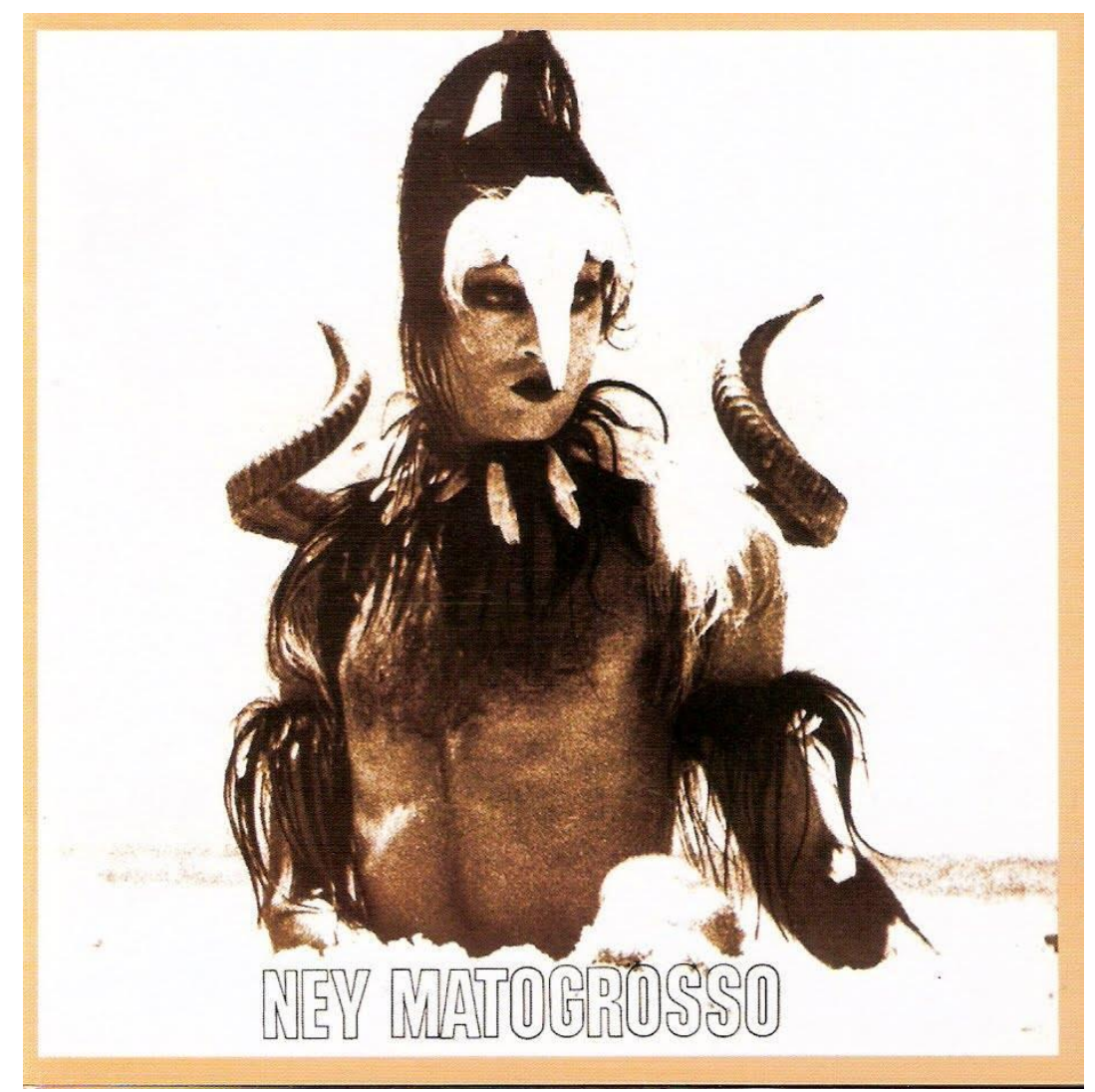

Abre-se o programa da performance de Ney Matogrosso, como uma primeira fase performativa. (Arte gráfica e identidade visual de Água do Céu- Pássaro) Foto: Luís Fernando Borges; Arte da Capa: Rubens Gerchman; Arte final: Oscar Paolillo.

Fonte: Álbum relançado em 2008.

Esse procedimento [re]presentacional, nas atividades audiovisuais de Ney Matogrosso, em 1975, conferiu a difusão de outra figuração do humano, equivalendo-se, salvaguardando as diferenças culturais, ao que Turner afirma ser: "[...] coincidência de processo de noções opostas em uma única representação caracteriza a peculiar unidade do liminar; o que não é nem isso, nem aquilo, e, no entanto, é ambos" (TURNER, 2005, p.144).

Em Água do Céu- Pássaro, na introdução da música Homem de Neanderthal , construída com a sonoridade de aves e macacos, o som do correr de rios, chuva e trovoadas, intercaladas com o 
som do berrante; seguido de um grito em eco eloquente da voz do cantor, em uma forma esquizofrênica que anuncia o personagem hibrido (homem/bicho), nos seguintes versos compostos por Luís Carlos Sá: "Eu sou o homem de Neanderthal/ Eu vivo apenas com meus próprios meios/ Eu vivo em penas com meus sentimentos/ Nasci de um povo primitivo." Desse modo, vocaliza-se o ser liminar que se visualiza na capa do álbum.

A canção América do Sul transpõe esse ser liminar configurado, segundo Bené Fonteles, a experiência midiática entre a figura humana e o "elemental em um papel xamã" (FONTELES, 2002, p.163-164), captada e registrada em audiovisual. Como símbolo da liberdade da América do Sul, reafirmado na fusão do homem e o animal, as sonoridades da natureza que se sobressaem no término da canção, exprimem os sons de pássaros (águias/araras) voando em revoada que completam a composição simbólica da liberdade clamada pelo homem primitivo posto em cena. Reitera-se o processo de enunciação do Homem de Neanderthal.

A exortação pela liberdade da América do Sul, posta em pauta naquele contexto, em que os países latino-americanos se encontravam sob a custódia de regimes autoritários (militares), apareceu como um grito pela liberdade, expressada por um hibrido. Tal clamor vindo dos versos de Paulo Machado são vocalizados em agudo som: "Deus salve a América do Sul / Desperta, ó claro e amado sol / Deixa correr / Qualquer rio que alegre esse sertão / Essa terra morena, esse calor / Esse campo molhado de suor..." Uma ampliação desse apelo se estendeu a mídia televisiva, no dia 29 de agosto de 1975, no semanário Fantástico ${ }^{9}$, na combinação da música e vídeo (videoclipe).

Nesse videoclipe, o personagem aparece dançando em movimentos frenéticos em cima de uma pedra, aludindo uma dança tribal em prol da libertação da América do Sul. $O$ cenário é a paisagem natural do Rio de Janeiro, em que o artista a fim de dar sentido ao seu homem pássaro, sobrevoou o mar da cidade pendurado em um helicóptero sem portas. Essa dimensão simbólica/ritualística que essa canção em combinação com outros elementos que concentram a performance de Ney Matogrosso, compôs a transmutação que confunde uma possível identificação, como expressa o próprio artista:

Ah, parecia aquilo que eu tinha puxado com a roupa trazia um outro ser. Não
era eu. Eu estava consciente, mas dava passagem claramente para alguma
coisa que a roupa toda colocava.... Eu acredito que seja um estado de transe,
mas era consciente. Mas, eu estava num espaço diferente, sim; num espaço
psíquico. Estar ali, naquele momento, era um ato ritual mesmo, como
também fazer foros naquela figueira gigantesca, na Praia de Filgueiras, onde

9 Esse videoclipe tornou-se um marco para a relação entre imagem e música no formato para televisão. Nesse caso América do Sul inaugura o "padrão globo" de gravação audiovisual que se perpetrou com sucesso até boa parte dos anos da década de 1980, vindo a ser superado com a chegada da MTV na década de 1990, e também pela consolidação das produtoras de audiovisual. América do Sul se destacou por ser gravado fora de estúdios da emissora, como afirma Rodrigo Faour, no texto de relançamento do álbum no formato compact disc (cd) no Box Camaleão: "É considerado um dos primeiros clipes de MPB, por ter lançado mão de recursos requintados na produção fora de estúdios. O trabalho foi longo, com locações em São Conrado e no Alto da Boa Vista, no Rio, e grande parte filmada no ar, mostrando o cantor sobrevoando uma série de paisagens" (FAOUR, 2008; SOARES, 2009). 
Luís [fotógrafo] morava com Luli. Eu estava diante daquela árvore e sabia o poder dela; e estava tentando me integrar aquilo tudo. (FONTELES, 2002, p.162).

$\mathrm{Na}$ condição liminar, a ambivalência produz outros arquétipos, ou, retoma arquétipos abandonados pelos projetos estruturais, conferindo uma "antiestrutura social", até mesmo evidencia uma contracultura. Sob esse aspecto, Victor Tuner elucida que, em caráter substancial, ao se referir às communitas, artistas possibilitam também a reclassificação, ou, a releitura da percepção social; sendo pela liminaridade/liminóide que o homem emite, parafraseando Carlo Ginzburg (1989), "seus, mitos, emblemas e sinais":

Contudo, a communitas só se torna evidente ou acessível, por assim dizer, por sua justaposição a aspectos da estrutura social ou pela hibridação com estes. [...] Os profetas e artistas tendem ser pessoas liminares ou marginais, "fronteiriços" que se esforçam com veemente sinceridade por libertar-se dos clichês ligados às incumbências da posição social e à representação de papéis, e entrar em relações vitais com outros homens, de fato ou na imaginação. Em suas produções podemos vislumbrar por elementos o extraordinário potencial evolutivo do gênero humano, ainda não exteriorizado e fixado na estrutura. (TURNER, 2010, p.123-124).

Essa ação de interação não rígida, ou acontecimento, notabiliza a relação emitida entre o artista, o público e a obra, completando-se as interlocuções dispostas, anteriormente, nas atividades performáticas também enunciadas em mídias diferentes responsáveis pelo efeito liminóide da enunciação da subversão. A expressão de busca pela liberdade é impregnada na persona do Homem de Neanderthal, nessa proposição é que se realiza a catarse das intersubjetividades reprimidas pela estrutura social afluente.

Desse modo, América do Sul completa uma experiência pré-anunciada nos processos midiáticos que constituem a obra, como expõe Dawsey, a partir da perspectiva de Turner sobre performance e experiência: "Performance - termo que deriva do francês antigo parfournir, "completar" ou "realizar inteiramente" - refere-se, justamente, ao momento da expressão. A performance completa uma experiência" (DAWSEY, 2007, p.532).

A queixada usada em América do Sul expressa a agressividade como interface da subversão no clamor pela liberdade, responsável por completar a experiência ultrajante. Esse canto de libertação foi recebido em dos espetáculos no Hotel Nacional por um artista plástico de um modo 
inusitado, ou uma fissura, interstício que completou o sentido da experiência que o artista atribuiu como expectativa sob a obra, como aponta o artista a Rodrigo Faour (2008):

\begin{abstract}
Durante a temporada, pelo menos um fato merece destaque. Com uma assustadora queixada de boi na mão, ao final do show, ele brava os versos: "Despertaaaa [sic], a América do Sul! ", levantando-a de forma ameaçadora. Uma noite, um sujeito, que era artista plástico, ficou dançando com uma melancia e na hora que Ney encenava este número, colocou-a próximo de seus pés, em pleno palco. $O$ cantor não titubeou. "Peguei aquela queixada e rachei a melancia! $O$ povo veio todo aos meus pés para agarrar a fruta $e$ comê-la. Virou um verdadeiro happening", ri.
\end{abstract}

América do Sul, nesses termos de liminaridade, perpassa o sentimento de "latinidade" na composição performática de Ney Matogrosso, extrapolando a esfera libertadora de sua obra ao contexto de conjuntura política reguladora no Brasil. Não obstante, se estende a mesma conjuntura alastrada pela América Latina na segunda metade do século XX. A proposição ritualística exposta nesta canção, em sua construção visual e sonora, deu passagem a outro personagem liminar presente na estética libertadora de Ney Matogrosso, a figura do bandido, em que o artista explicitou determinada agressividade:

E ele [Homem de Neanderthal] colocou um arquétipo para fora e depois passou pro resto. Foi uma sequência muito interessante, por que logo depois o disco "Bandido" - que eu era visto com um corpete de pele -, era mais agressivo, com aquela faca de pessoa da fronteira... Era um arquétipo que tomou vida. Aquilo não era um ser humano. Do "Bandido" em diante, tudo o que usei foi como fantasia. E um recurso cênico, mas também era a minha defesa absoluta. [América do Sul] é um canto de guerra, com o qual eu encerrava o show "Bandido" e a mesma queixada que usava no "Homem de Neanderthal". E quando fui cantar na Argentina as pessoas me achavam muito agressivo, mas entenderam que é necessário. É uma coisa que, como "Rosa de Hiroshima" e "Sangue Latino", eu cantei durante todos esses anos. (MATOGROSSO, 2002, p.165)

\title{
Bandido: o que salva é sua insensatez
}


Em Bandido, personagem liminar que configurou, segundo Ney Matogrosso e parte da recepção, uma agressividade mais próxima do humano. Porém, tal figura se projeta em um sujeito marginal que, estrategicamente, não se aproxima explicitamente da representação tradicionalizada do bandido difundida pelos filmes de Western hollywoodianos. Ney Matogrosso construiu um bandido hibrido na fusão com cigano (a), uma boneca cobiçada ${ }^{10}$, que se desloca na construção do disco posterior - Pecado-, em 1977.

Figura 2- Bandido em sua enunciação imagética e performática (Capa do disco Bandido).

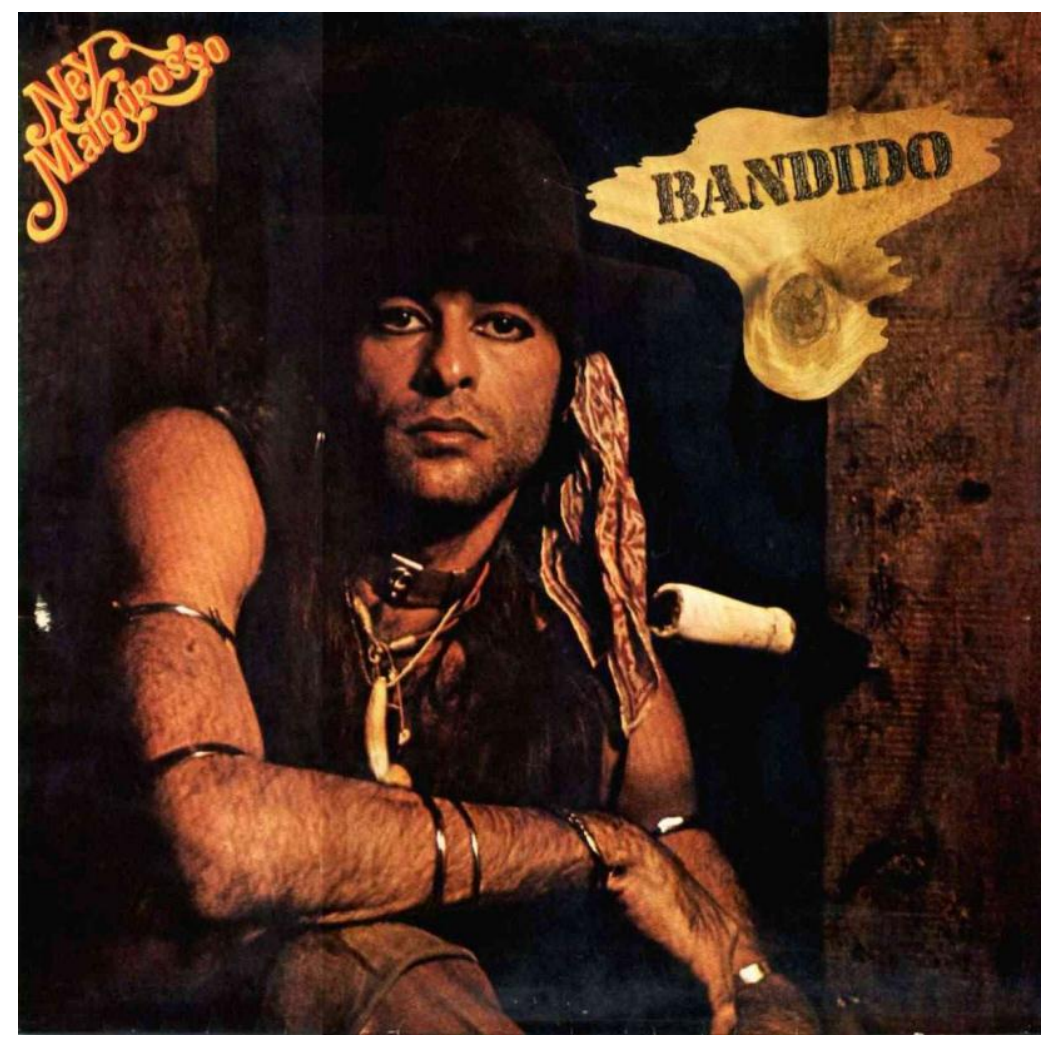

Fonte: Disco relançado em 2008.

Nessa linha performática, o espetáculo de Bandido estreou em 1976, num lugar mais propício para personificação da performance com o personagem, a penitenciaria Lemos de Brito, no Rio de Janeiro. Executando-se assim, outra tendência performática marginal. Ney Matogrosso foi escolhido pelos detentos da penitenciária como o símbolo da liberdade, em um lugar que, sumariamente, não há liberdade. Mas, foi essa experiência que culminou na construção do fonograma que já tinha

10 Uma das músicas que compõe o repertório do show Bandido e o disco Pecado (1977), música essa precedida do streep-tease do bandido, e quando Ney Matogrosso a cantava conferia um sentido lascivo e erótico ao personagem; compõe-se, então, a cena como interface da ambiguidade. 
como mote a canção Bandido Corazón, composta por Rita Lee. Dessa maneira, seguiu com o espetáculo entre 1976 -1977:

Daí começou o "Ney Matogrosso Bandido". Inicialmente, apenas um show em cima do novo gênero. [...]. Foi então que 2000 presos da Penitenciária Lemos de Brito, no Rio de Janeiro, numa enquete para escolher quem faria o show de encerramento do festival de música promovido por eles, escolheram o que Ihes representava liberdade: Ney Matogrosso. Com a idéia na cabeça, o convite não poderia deixar de ser mais oportuno. Ney subiu no palco; na plateia 2000 pessoas com os olhos arregalados, prestando muita atenção naquele corpo magro, que não parava de mexer como uma serpente e naquela voz afinada. Alguns comentários: "Parece com a Carmem Miranda". E Ney foi cantando cada vez mais liberdade. "Canta Cubanacan"? E por que não? (PRATA, 1976, p.24-25).

Bandido compôs a continuação da performatividade da libertação, projetada desde o primeiro trabalho solo de Ney Matogrosso. Nessa continuidade, surgiu a figura do bandoleiro, em Feitiço (1978), obra em que a liminaridade se concretiza também pelo título da obra, por conseguinte, com no projeto gráfico que, logo, foi censurado pela nudez.

\section{Corpo, Nudez e Feitiço}

Entretanto, esse disco de 1978, trouxe Ney Matogrosso em sua dimensão total: a sexualidade como "oferenda aos orixás" (FAUOR, 2008), possivelmente consagra-se a Eros. A nudez não é castigada, mas sim provoca quem castiga, é o efeito da transgressão:

A ação decisiva é o desnudamento. A nudez se opõe ao estado fechado, isto é, ao estado de existência descontínua. É um estado de comunicação que revela a busca de uma continuidade possível do ser para além do voltar-se sobre si mesmo. Os corpos se abrem para a continuidade através desses canais secretos que nos dão o sentimento da obscenidade. A obscenidade significa a desordem que perturba um estado dos corpos que estão conformes à posse de si, à posse da individualidade durável e afirmada. Há, ao contrário, desapossamento no jogo dos órgãos que se derramam no renovar da fusão, semelhante ao vaivém das ondas que se penetram e se perdem uma na outra. Esse desapossamento é tão completo que no estado de nudez, que o anuncia, e que é o seu emblema, a maior parte dos seres humanos se esconde, mais ainda se a ação erótica, que acaba de desapossá-los, acompanha a nudez. O desnudar-se, visto nas civilizações 


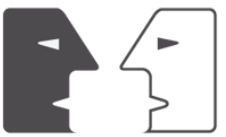

ANTÍTESES

onde isso tem um sentido pleno, é, quando não um simulacro, pelo menos uma equivalência sem gravidade da imolação. Na Antiguidade, a destituição (ou a destruição) que funda o erotismo era bastante sensível para justificar uma aproximação do ato de amor e do sacrifício. (BATTAILLE, 1987, p.14).

Esses primeiros álbuns traçaram uma perspectiva de apropriação coerente na concepção de fronteira, como o lugar de expansão e subversão, da liberdade, o próprio artista percebe essa dimensão:

O "Bandido" era fronteiriço. Era imagem da fronteira mesmo. Depois veio o disco "Pecado", cuja a foto da capa que eu queria pôr no disco foi vetada pela censura. Era eu me beijando num espelho oval. Era uma coisa bem narcisista, mas era abuso. Eu estava beijando um homem na boca; que era eu mesmo. Era desafiar, mas não deixaram coloca-la na capa e ela entrou dentro do disco. (FONTELES, 2002, p.167).

Figura 3- Fusão entre Bandido e Cigano - a marginalidade se estende cada vez mais erótica, agora em Pecado (Capa do álbum Pecado 1977).

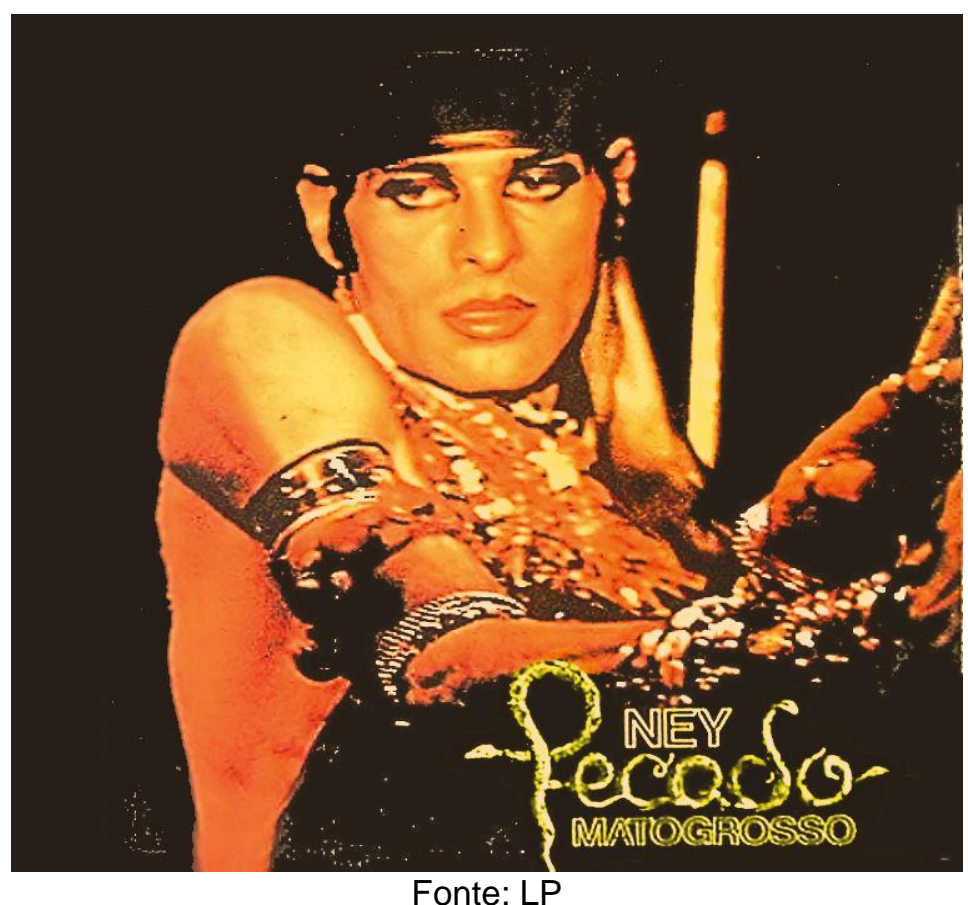


Figura 4- Corpo oferenda - ode a Eros (Encarte do LP Feitiço 1978)

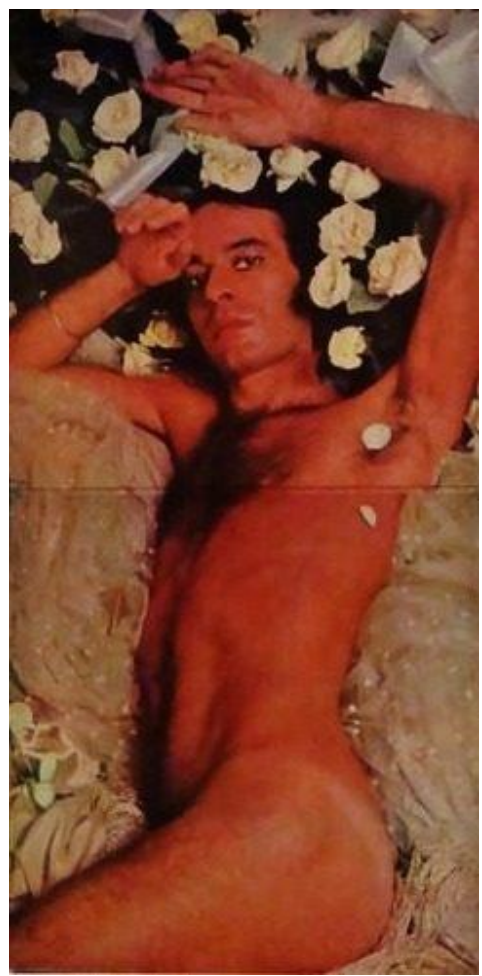

Fonte: LP

Frente a essas ações, a performance do artista continuou a enfrentar a fronteira, seja ela qual fosse, como a de gênero exposta no álbum Feitiço, em que o artista vocaliza e interpreta os versos do médico Mauro Kwitko que, poeticamente, expressam a condição de fronteira, não só de gênero, mas de tudo que oprime e congela o Eros, ao interpretar Mal necessário, o artista chancela sua estética da subversão, que admite o ser em suas contradições geralmente aprisionadas na regulação social:

Sou um homem, sou um bicho, sou uma mulher / Sou a mesa e as cadeiras deste/Sou um homem, sou um bicho, sou uma mulher/Sou a mesa e as cadeiras deste cabaré/ Sou o seu amor profundo, sou o seu lugar no mundo/Sou a febre que Ihe queima mas você não deixa/ Sou a sua voz que grita mas você não aceita/ $O$ ouvido que Ihe escuta quando as vozes se ocultam/Nos bares, nas camas, nos lares, na lama/Sou o novo, sou o antigo, sou o que não tem tempo/O que sempre esteve vivo, mas nem sempre atento/O que nunca Ihe fez falta, o que Ihe atormenta e mata/Sou o certo, sou o errado, sou o que divide/O que não tem duas partes, na verdade existe/Oferece a outra face, mas não esquece o que lhe fazem/Nos bares, na lama, nos lares, na cama. (KWITKO, 1978, s.n.) 


\section{O impávido índio}

Por último, destacamos o sujeito liminar e arquétipo simbólico utilizado pelo artista em 1982, o índio, da obra Mato Grosso. Esse índio é o personagem que consideramos liminar, sobretudo, por integrar a intenção performática de Ney Matogrosso que, ao corporifica-lo, emana a voz de sujeitos evidenciados pelas lutas cravadas nos movimentos sociais, como o grupo de afirmação homossexual - Somos.

Ney Matogrosso pronunciou essas demandas sem engajamento específico, porém, as configurou através de símbolos das identidades sociais brasileiras, por exemplo, por intermédio do carnaval, malandro e o caipira. Todos esses sobrepostos na figura do índio, já enunciado na capa do álbum. Assim, o artista concretizava os sentidos poéticos de canções, como Alegria Carnaval, Uai Uai, Por Debaixo dos Panos, entre outras.

Nesse caldo de efervescência social, Mato Grosso é uma obra (fonograma/material gráfico/espetáculo) que conferiu a evidenciação da tríade desejo/inversão/riso em caráter de transgressão, assumido pelo erotismo, máxime o homoerótico, diante do processo de reabertura política brasileira, como arma de combate às interdições impostas pelos meios e agentes estabelecedores da ordem (normativas). A obra, tanto quanto as outras supracitadas, toma sentido pela clarividência dos processos históricos que se delinearam no processo de reabertura política.

Figura 5- O índio carnavalizado no palco, em Mato Grosso (1982)

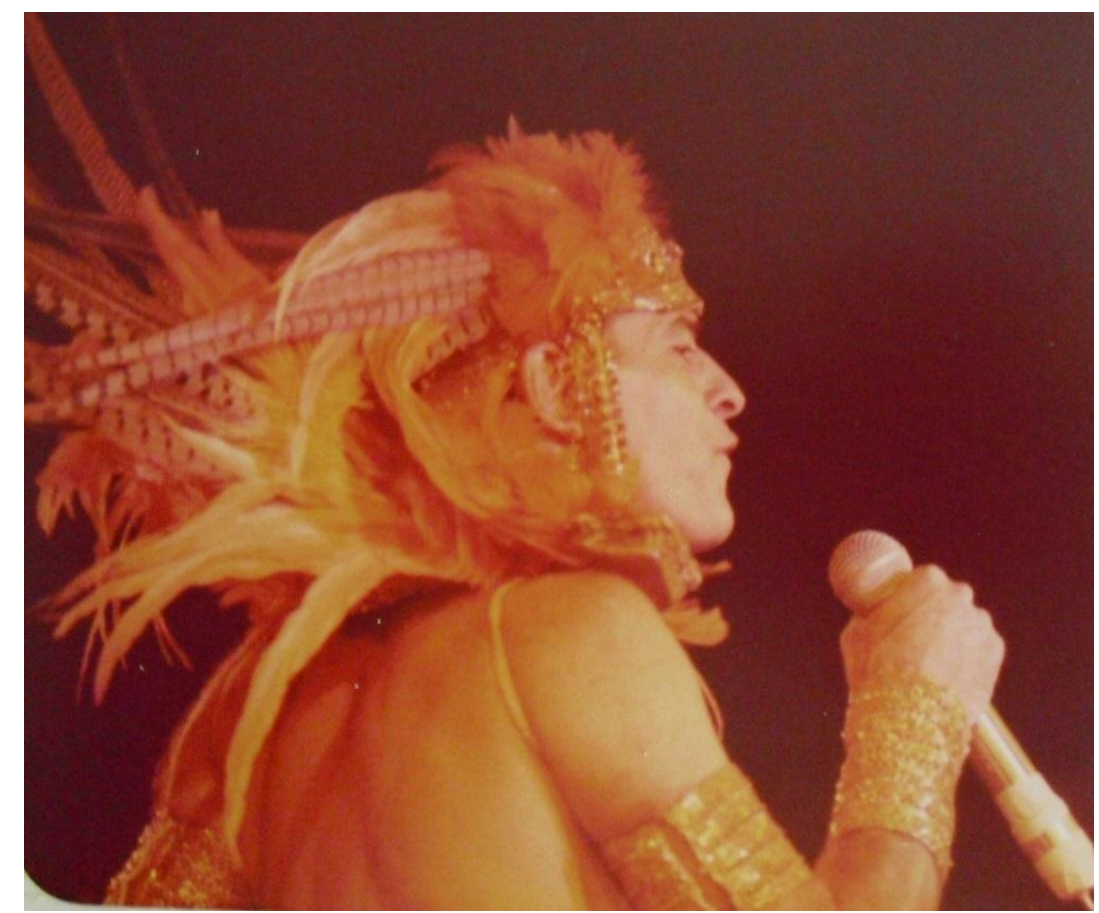

Fonte: Acervo Pessoal de Ney Matogrosso. 


\section{Considerações Finais}

$\mathrm{Na}$ condição de interprete, Ney Matogrosso, como expoente de uma indústria cultural reafirmada no Brasil da ditadura civil militar, não precisaria, caso estivesse ligado somente a construção de um material de cultura meramente vinculado a um projeto de consumo massivo, almejar e construir uma linha performática calcada na enunciação de sujeitos marginais. Bastaria somente cantar, sobretudo por sua qualidade vocal já chancelada em seus primeiros trabalhos.

Entretanto, esses sujeitos construídos a cada álbum apareceram processual e ritualisticamente, nas etapas midiáticas que articularam corpo, texto, imagem e sonoridade, como enunciados da construção de uma performance, visando o projeto estético de subversão.

Esses processos completavam a experiência no espetáculo do artista, onde se personificava o homem elemental, o bandido e o índio. Os processos e os meios caracterizaram a premissa liminóide na obra de Ney Matogrosso, com a propensão de construção de situações cênicas e enunciativas, na ampliação de textos e composições em suas obras. Ney Matogrosso, nesses procedimentos midiáticos, firmou os versos da música Idade de Ouro, de Jorge Omar e Paulo Mendonça: "Sou quem sou, e não sou nada, sou uma história já contada".

Explicita-se, portanto, a tentativa de expressar-se em meio ao mundo da fragmentação, das aparências, da produtividade agressiva que alija a liberdade, maximiza pela tendência econômica. Foram essas tensões da sociedade tecnocrática e repressiva em solo brasileiro que fizeram com que, Ney Matogrosso, como outros interpretes, tivessem a capacidade de negociar com os administradores e/ou reprodutores desses mecanismos, como as gravadoras, a fim de difundir esteticamente ideais e alternativas de catarse da subversão, com expectativas visadas na intenção de liberdade, inclusive a sexual.

Em suma, a partir desse breve apanhado sobre a composição de personagens performáticos de Ney Matogrosso, podemos vislumbrar uma partilha do sensível que produziu e tencionou os constructos sociais e suas demandas comuns, pelo terreno da estética que, segundo Ranciére, dispõe jogos de experiências que se facultam como ação política, afinal emanam possibilidades, maneiras, visibilidades, sonoridades; efetivam um pensamento:

A partilha do sensível se faz ver quem pode tomar parte no comum em função daquilo que faz, do tempo e do espaço, em que essa atividade se exerce. Assim, ter esta ou aquela "ocupação" define competências ou incompetências para o comum". [...] A política ocupa-se do que vê, e do que se pode dizer, sobre o que é visto, de quem tem competência para ver a qualidade para dizer, das propriedades do espaço e dos possíveis no tempo. 
" [...] "As práticas artísticas" são maneiras de fazer nas relações de fazer e nas suas relações com maneiras de ser e formas de visibilidade. Ora, tais formas revelam-se de saídas comprometidas com um certo regime de política, um regime de indeterminação das identidades, de deslegitimação das posições das palavras, de desregulação das partilhas do espaço e do tempo. (RANCIÉRE, 2009, p.16-18).

A partilha do sensível que a estética da subversão, comungada por Ney Matogrosso, difundiu, sobretudo, na escolha dos personagens liminares/marginais, construíram a trama visual em suas obras ao longo de quarenta anos de carreira. Por vezes, liberaram a representação de uma perspectiva contracultural, que apresentou olhares de indeterminação sobre o sujeito, como arma de desregulação do regime autoritário que inferiu sob as potencialidades criativas próprias do humano, como a dimensão do desejo que tende a ser dissolvido por sistemas históricos de regulação.

A liminaridade acusada por Ney Matogrosso, dinamizou-se pela intencionalidade do corpo em integrar a performance como aparato impresso e impressor das mídias. Profanou seu corpo pela dimensão ritual e erótica.

Desse modo, Ney Matogrosso arrombou o "cadeado" aprisionador de Eros, em uma ditadura, com a chave erótica que comandou a partilha sensível da subversão. Oportunizou pelo "paradigma da performance", do corpo como "puro aparato sensório perceptivo e cognitivo" (NORONHA, 2005, p.136), a potencialidade libertadora do sexo e da marginalidade dos sujeitos postos como figurantes no palco da estrutura social.

$\mathrm{Na}$ cena de Ney Matogrosso, o sujeito liminar é retirado da margem e posto no centro, difundido massivamente pela indústria cultural, concretizando-se, assim, uma subversão filmadora do paradoxo de uma contracultura exposta, difundida, recebida em uma cultura. Anuncia o corpo como instrumento, como afirma em Pecado, na música Com a Boca no Mundo, a libertação de Eros como missão.

\section{Referências}

BATAILLE, Georges. O Erotismo. Porto Alegre: L\&PM, 1987.

BRAIT, Beth; MELO, Rosineide de. Enunciado/ enunciado concreto/ enunciação. In: BRAIT, Beth.

(Org.). Bakhtin conceitos-chave. 5. ed. São Paulo: Contexto, 2013. 
CLÜVER, Claus. Intermidialidade. Pós, Belo Horizonte, v.1, n.2, 2007.

DAWSEY, John C. Sismologia da Performance. Revista de Antropologia, São Paulo, v. 50, n.2, 2007.

FAUOR, Rodrigo. Bandido. Encarte. IN: MATOGROSSO, Ney. Bandido. Rio de Janeiro: Continental, p1976. 1 disco sonoro (33min.). Box Camaleão. Rio de Janeiro: Universal Music, c2008.1 CD.

FIGUEIREDO, Vilma. Autoritarismo e Eros. São Paulo: Ed. Perspectiva, 1992.

FONTELES, Bené (Org.). Ney Matogrosso: ousar ser. São Paulo: SESC, 2002.

GUINZBURG, Carlos. Mitos, emblemas, sinais: morfologia e história. São Paulo: Cia. das Letras 1989.

KWITKO, Mauro. Mal Necessário. IN: MATOGROSSO, Ney. Feitiço. Rio de Janeiro: Warner (Elektra Records), p1978. 1 disco sonoro (33min.). Lp 33 rotações.

LANGER, Susanne. Filosofia em Nova Chave. São Paulo: Perspectiva, 2004.

LANGER, Susanne. Sentimento e Forma. São Paulo: Perspectiva, 2011.

MARCUSE, Herbert. A Dimensão Estética. Lisboa: Edições 70, 1981.

MARCUSE, Herbert. Eros e Civilização. 6.ed. Rio de Janeiro: Zahar Editores, 1975.

MATOGROSSO, Ney PRATA, Leonel; QUEIROZ, Nico Pereira.- mocinho e bandido. Revista Música. São Paulo: Imprima Comunicação e Editora, dezembro de 1976.

MATOGROSSO, Ney. Água do Céu - Pássaro. Rio de Janeiro: Universal Music, 2008. cd.

MATOGROSSO, Ney. Bandido. Rio de Janeiro: Universal Music, 2008. cd.

MATOGROSSO, Ney. Feitiço. Rio de Janeiro: Universal music, 2008. cd.

MATOGROSSO, Ney. Mato Grosso. Rio de Janeiro: Universal music, 2008. cd.

MATOGROSSO, Ney. Pecado. Rio de Janeiro: Universal music, 2008. cd.

MORELLI, Rita C. L. Indústria Fonográfica um estudo antropológico. 2. ed. Campinas: Ed. Unicamp, 2009.

NORONHA, Márcio Pizarro. Imagens do corpo e embodiment das imagens. A circulação da imagem corporal em uma perspectiva histórica (artística) e antropológica (estética). Revista Sociedade e Cultura, Goiânia, v. 8, n. 2, 2005. 
NORONHA, Márcio Pizarro. Linhas cruzadas e uma Plataforma de Observação: Das Conversações entre História, Cultura Visual e Filosofia. 2004. Disponível em: <http://marciopizarro.wordpress.com/2008/09/10/exposicaoafonsofrantzghiorziguimaraes/> Acesso em: 29 dez. 2014.

PIZINI, Joel. Olho Nu. Documentário / Cor / Dolby 5.1 / 101 minutos. Rio de Janeiro: Canal Brasil, 2012.

PRATA, Leonel; QUEIROZ, Nico Pereira. Ney Matogrosso - mocinho e bandido. Revista Música. São Paulo: Imprima Comunicação e Editora, dezembro de 1976.

QUEIROZ, Flávio de Araújo. Ney Matogrosso: sentimento contramão transgressão e autonomia artística. 2009. Tese (Doutorado em Sociologia) - Universidade Federal do Ceará, Fortaleza, 2009.

RANCIÈRE, Jacques. A partilha do sensível: estética e política. 2. ed. Tradução de Mônica Costa Netto. São Paulo: Exo/ Editora 34, 2009.

SARDY, Severo. Escritos sobre o corpo. São Paulo: Perspectiva, 1979.

SOARES, Thiago. A Construção Imagética dos Videoclipes: Canção, Gêneros e Performance na Análise de Audiovisuais da Cultura Midiática. 2009. Tese (Doutorado em Comunicação e Cultura Contemporânea) - UFBA, Salvador, 2009.

TURNER, Victor. Dramas, Campos e Metáforas. Rio de Janeiro: Eduff, 2008.

TURNER, Victor. Floresta de Símbolos: aspectos do ritual Ndembu. Rio de Janeiro: Eduff, 2005.

TURNER, Victor. O Processo Ritual Estrutura e Anti Estrutura. Petrópolis: Vozes, 2010.

WILLIAMS, Raymond. Base e superestrutura na teoria cultural marxista. Revista USP, São Paulo, n.65, p. 210-224, mar./maio 2005.

ZUMTHOR, Paul. Performance, Leitura e Recepção. Tradução de Jerusa Pires Ferreira e Suely Fenerich. 2. ed. São Paulo: Cosac Naify, 2007.

Recebido em 08.02.20115 - aprovado em 09.09.2015 